\title{
A Reflection on the Artists and Academics Exhibition
}

\author{
Eri Tsukamoto* \\ Department of Sociology, University of Warwick \\ *Correspondence: E.Tsukamoto@warwick.ac.uk
}

\begin{abstract}
On 26 November 2016, the Artists and Academics Exhibition was held at Fargo Village in Coventry. The Exhibition was a collaborative project between seventeen $P h D$ researchers from the University of Warwick and seventeen local artists, in which each artist created a piece inspired by a research idea. The Exhibition fostered active conversation between artists, academics and the general public, thereby encouraging all participants to talk about academic works in an informal setting and to explore new ideas and perspectives. Collaborative projects like the Exhibition thus benefit all who participate, and wider participation should be encouraged. Negative perceptions of public engagement may be changed through such an active participation.
\end{abstract}

Keywords: public engagement and impact, collaboration, exhibition, artists and academics, interdisciplinarity, animal studies

Peer review: This article has been subject to a double blind peer review process

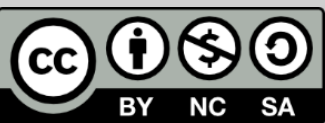

(C) Copyright: The Authors. This article is issued under the terms of the Creative Commons Attribution NonCommercial Share Alike License, which permits use and redistribution of the work provided that the original author and source are credited, the work is not used for commercial purposes and that any derivative works are made available under the same license terms.
Public engagement has been the subject of intensive study since higher education institutions became aware of its importance. However, a gap between the perceived importance of public engagement and actual practices was revealed by Richard Watermeyer (2015). Watermeyer interviewed 40 UK-based academics on their perceptions towards public engagement, and found that many researchers perceived public engagement as inconsequential to their academic career-or even as a sacrifice of academic career. Because its impact on their career is perceived as minimal, public engagement is less prioritised than the other supplementary activities of early career researchers, such as those surrounding teaching, conferences and publications. This stigma surrounding public engagement needs to be changed. Though, the change has been slowly taking place. For instance, the new feature of Research Excellence Framework (REF) in 2014, was impact of research beyond academia, which encourages higher education institutions to support and practice public engagement. Nevertheless, as Teresa Penfield et al. (2014) pointed out, the assessment itself faces challenges 
of evaluating research impact such as time lag between research and impact and changing nature of impact. There are more issues need to be addressed in order to promote changes public engagement confronts.

To experience public engagement first-hand is one way that this change may be enacted. The Artists and Academics Exhibition was led by Dr Emma Parfitt from the University of Warwick. Dr Parfitt gathered seventeen Coventry-based artists and seventeen $\mathrm{PhD}$ researchers from the University of Warwick, and instructed the artists to create a variety of art pieces inspired by the PhD research idea of their choice. This innovative collaboration connected two creative fields-academia and the arts-and thereby enabled both parties to reach a diverse audience who might have otherwise never engaged with these fields. To experience such an exhibition first-hand has the potential to change current, negative perceptions of public engagement by fostering a generative exchange of both knowledge and experience.

For the exhibition, the artist Frieda Van De Poll and I worked on a collaborative project. Frieda and I share as a mutual interest in the representation of animals: my research focuses on audience reactions to the televisual representation of animals, while Frieda's works frequently contain, and are concerned with on a critical level, animal imagery. Participation in a collaborative project brought fresh insights to my research. I perceived the use of animal images in media as a generally positive practice: children's books, for example, often deploy animals in a didactic sense, to teach children morals; here, animals enable a type of story-telling entirely unconcerned with gender, class or ethnicity. Frieda questioned the anthropocentrism essential to this practice, rightly pointing out that these animals were anthropomorphised and imbued with particular, and very human, qualities. Such practices, said Frieda, may lead people to judge animals based on their human values and attributes. Even as symbolic forms, animals are still used by humans and for human interests. This conversation was one of many that prompted me to rethink my research.

The imagination, creativity and knowledge of the participating artists was inspiring. Consider Frieda's knowledge of animal images in religion, for instance: animals, she told me, are used often to represent deities, and such representations can reflect both positive and negative aspects of human life. For example, Ganesha, a Hindu god with an elephant head, is often associated with knowledge and intelligence. I thus came to realise that animals are used commonly to reflect a variety of human life. Before our conversation, I was considering only the changing representations of animals in television programmes; afterwards, following our conversation, I drew from a wider range of sources and considered the 
symbolic use of animals more broadly by humanity. Thus a connection between the religious representations of animals and my current research prompted a shift in my perspective on my work, and Frieda's knowledge and experience of the arts functioned to broaden my conceptual horizon.

On the day of the exhibition, Fargo Village was filled with a variety of artforms. Frieda's work was a cut-out piece, entitled 'Revenge of the Animals'. Beneath its bright, cheerful surface are undertones of anger and fear towards those animals appropriated in the service of human ends; the work functions to critique the anthropocentric use of animals, and conveys an increasing sense of unease and distrust towards the exploitation of animals in modern society. In short, her artwork depicted deftly the essence of my research by criticising exploitation of animals from animal's perspective. Indeed, all of the artworks exhibited beautifully represented their research ideas. Beyond encapsulating their research ideas and transmitting them in another format, each work invited an increased curiosity and thematic engagement with their scientific touchstones. Consider, for example, Jenny Egarton's work, which was inspired by Catherine Lester's research, in which a miniature children's room was populated with references from horror films. Egarton's work went beyond capturing Lester's PhD research on children's horror films, inviting the audience to question the connection between each reference and childhood.

I could see many interactions in the exhibition among academics, artists and the general public with positive and friendly exchanges of opinions and knowledge. The questions were both targeted towards artists and academics. For instance, the artists were asked about their creative processes and uses of materials while the academics were asked about their research methods and processes. Such interactions reflected the positive engagements for both artists and academics. In addition, the exhibition welcomed a variety of age groups, and it demonstrated how the collaborative project can capture wider variety of audience. As often, $\mathrm{PhD}$ research is not accessible to the general public due to knowledge barriers or academic jargons. On the other hand, art is accessible by a wide variety of people. The collaborative project invited a broad audience to explore the work of academics and the kinds of knowledge they create. The exhibition opened up people's interests towards academic subjects and rendered a friendly environment to explore ideas without knowledge or vocabulary requirements. 
Art worked as a gateway for people, academics and non-academics alike, to engage with doctoral research ideas. The experience to engage with a wide-ranging audience could be rewarding and interesting experience for academics involved. Personally, I found the collaborative project inspiring, refreshing and valuable. I gained new insights into my research through the collaborative experiences and exchanges of ideas. Also, faceto-face interactions with a variety of people gave me the confidence to engage with other academics and the general public. I received great responses from other PhD researchers as well. Several researchers who visited the exhibition were enthusiastic to participate in the next collaborative project. A variety of research might also lead to interdisciplinary research or new collaborative projects by inspiring each other and exchanging ideas.

Despite being seen as a 'loss' in academic career and 'sacrifice' of time and effort, public engagement renders researchers skills which are often dismissed as 'soft' skills such as communication and engagement. The artists and academic exhibition was an innovative collaboration to engagement with the general public in a friendly and open atmosphere and to improve skills. Moreover, an expansion of knowledge and experience through a collaborative project would be beneficial to all early career researchers. The collaborative project promoted a positive impact on academics, artists and the general public. As Budd L Hall noted, public engagement 'is a significant trend, to which continuing education has much to offer and from which it has much to gain' (2009: 12). Higher education might still be considered to be an ivory tower, which divides academics and others outside academia. The chance for people to be exposed to knowledge and ideas within postgraduate studies could break the boundaries between academics and nonacademics and between academics in different disciplines.

\section{Acknowledgements}

I sincerely thank to Dr Emma Parfitt for giving me the amazing opportunity to take part in the exhibition.

I also wish to thank Frieda van de Poll for her beautiful artworks, her great insights into the representations of animals and the exciting collaborative experience. 


\section{References}

Hall, B. L. (2009), 'Higher education, community engagement, and the public good: building the future of continuing education in Canada', Canadian Journal of University Continuing Education, 35 (2), 11-23.

Watermeyer, R. (2015), 'Lost in the "third space": the impact of public engagement in higher education on academic identity, research practice and career progression', European Journal of Higher Education, 5 (3), 331-42.

Penfield, T., Baker, M. J., Scoble, R., \& Wykes, M. C. (2013), 'Assessment, evaluations, and definitions of research impact: A review', Research Evaluation, 21-32.

To cite this article:

Tsukamoto, E. (2017). A Reflection on the Artists and Academics Exhibition. Exchanges: The Warwick Research Journal, 4(2), 227-231. Retrieved from: http://exchanges.warwick.ac.uk/index.php/exchanges/article/view/143 